\title{
sciendo
}

DOI: $10.2478 /$ pesd-2019-0002

PESD, VOL. 13, no. 1, 2019

\section{THE ANALYSIS OF THE CHEMICAL COMPOSITION OF PRECIPITATION DURING THE DRIEST YEAR FROM THE LAST DECADE}

\author{
Ágnes Keresztesi ${ }^{1,2}$, Réka Boga ${ }^{1,2}$, Zsolt Bodor ${ }^{2}$, Katalin Bodor ${ }^{1,2}$, \\ Szende Tonk ${ }^{3}$, György Deák ${ }^{4}$, Ion-Andrei Nita ${ }^{5,6 *}$
}

Keywords: precipitation chemistry, ionic composition, acid neutralization, source contribution, Principal Component Analysis (PCA)

\begin{abstract}
In order to investigate the precipitation chemistry, studies were carried out from January 2013 to December 2013 in Odorheiu Secuiesc and Miercurea Ciuc, Eastern Carpathians, Romania. During a period of eleven years (2006 - 2016), 2013 was the driest year. The rainwater samples were analyzed for $\mathrm{pH}$, major anions and cations. $\mathrm{HCO}_{3}{ }^{-}$concentrations were calculated based on the empirical relationship between $\mathrm{pH}$ and $\mathrm{HCO}_{3}{ }^{-} . \mathrm{NH}_{4}^{+}, \mathrm{Ca}^{2+}, \mathrm{SO}_{4}{ }^{2-}$ were the dominant ions in precipitation at both sites. The $\mathrm{pH}$ values varied from 6.75 to 7.46 Miercurea Ciuc, and from 6.69 to 7.67 in Odorheiu Secuiesc. The neutralization was mainly brought by $\mathrm{Ca}^{2+}$ and $\mathrm{NH}_{4}{ }^{+}$. Estimated ratios of seasalt fraction (SSF), non-sea-salt fraction (NSSF), and results from Spearman's rank correlation and Principal Component Analysis (PCA), showed that the acidic ions $\left(\mathrm{SO}_{4}{ }^{2-}, \mathrm{NO}_{3}{ }^{-}\right)$were derived from anthropogenic activities, $\mathrm{NH}_{4}{ }^{+}$ from soil fertilization, while $\mathrm{Ca}^{2+}, \mathrm{Mg}^{2+}, \mathrm{K}^{+}$originated from terrestrial source. These influence the precipitations ionic content, especially during droughts. Spatial variations and the rim effect of the Eastern Carpathians on precipitation chemistry is also shown.
\end{abstract}

\section{Introduction}

Precipitation is one of the best scavengers for removing particulate matter and gaseous pollutants from the atmosphere, providing information about both

\footnotetext{
${ }^{1}$ University of Pécs, Faculty of Natural Sciences, Doctoral School of Chemistry, Ifjúság 6, 7624 Pécs, Hungary

2 Sapientia Hungarian University of Transylvania, Faculty of Economics, Socio - Human Science and Engineering, Department of Bioengineering, Piaţa Libertăţii 1, 530104, Miercurea Ciuc, Romania

${ }^{3}$ Sapientia Hungarian University of Transylvania, Faculty of Sciences and Arts, Calea Turzi 4, 400193, Cluj Napoca, Romania

${ }^{4}$ National Institute for Research and Development in Environmental Protection, Splaiul Independenţei 294, 6th District, 060031 Bucharest, Romania

${ }^{5}$ Alexandru Ioan Cuza University, Bulevardul Carol I 11, 700506, Iași, Romania

6 National Meteorology Administration, Soseaua București-Ploiești 97, District 1, 013686, Bucharest,

Romania, ${ }^{*}$ Corresponding author, E-mail: nitaandru@gmail.com
} 
the main sources of pollutants and their migration processes (Ciężka et al., 2015). Precipitation has a considerable influence on the deposition amount of inorganic species (Pascaud et al., 2016). Numerous studies have shown the role of scavenging mechanisms of atmospheric pollutants, stating that lower precipitation amounts can cause greater pollutant accumulation and deposition (Cugerone et al., 2017; Ge et al., 2016; Pan et al., 2017; Xu et al., 2017). Air pollutants can be removed from the atmosphere during the in-cloud and belowcloud scavenging mechanisms (Wang et al., 2010; Zhang et al., 2013). Belowcloud scavenging processes are defined by the characteristics of the rain, including the raindrop size distribution and rainfall rate, as well as on the chemical nature of the particles and their concentrations in the atmosphere (Chate et al., 2003), leading to higher concentrations in lower precipitation samples (Anderson and Downing, 2006).

The accentuated spatial variability of atmospheric pollutants is influenced by the regional air mass circulations loaded with different pollutants and by the significant local contribution of atmospheric circulation regimes, developed at a local scale (Korodi et al., 2017; Petres et al., 2017). This variability is also influenced by the mountain systems that interrupt the circulation of air masses (Szép et al., 2018). In these conditions, the chemical composition of rainwater varies from region to region, due to influence of local sources, being an important issue for many regions worldwide, as it can increase stress in terrestrial and aquatic ecosystems, leading to eutrophication, affecting ecosystems or contributing to global climate change (Behera et al., 2013). In the $60 \mathrm{~s}$ and ' $70 \mathrm{~s}$ intra-Carpathian basins were heavily drained, causing significant water loss and lower evapotranspiration. This led to increased local anticyclonic conditions, with long episodes of static stability of the atmosphere, often involving thermal inversions, causing particulate matter and pollutants accumulation (Szép et al., 2017b, 2017a, 2016d, 2016a, 2016c, 2016b; Szép and Mátyás, 2014). These induced changes in the rainwater chemistry and neutralization processes. These local anticyclone conditions often overlap with regional and/or intercontinental anticyclones (Siberian High). The study area and the sampling sites cover two regions in the Eastern Carpathians. Miercurea Ciuc (46'22'N, 25'48'E, elevation $\sim 600 \mathrm{~m}$ ) lies in an intra-Carpathian, enclosed basin (Ciuc), and is one of the coldest areas in Romania. Odorheiu Secuiesc (46'18'N, 25'18'E, elevation $\sim 524 \mathrm{~m}$ ) is located in an extra-Carpathian region, with a milder, continental temperate climate. The vertical fragmentation of the landscape is due to the neo-eruptive chain of Eastern Carpathians, the Harghita volcanic mountains $(1800 \mathrm{~m})$, which dominates to East the Ciuc basin and to West the Transylvanian SubCarpathians, has a blocking role in front of the north-westerly cloudy systems 
loaded with rainfall. Hence, the intra-Carpathian basin is subjected to drought and to the accumulation of polluting materials. Local climatic factors that develop at the basins level, induce the accumulation of chemical compounds from both natural and anthropogenic sources, having a great influence on precipitation chemistry (Szép et al., 2019). The specific micro-climatology of the basin has been found to influence the quality of the ambient aerosols, by enriching them with anthropogenic or natural compounds (from the inside to the outside of the basin) and non-sea and sea salt constituents (Szép et al., 2017c). Emissions from small scales industries, road traffic, biomass burning and livestock breeding, could be one of the reasons for the differences found in the ionic composition of rainwater collected at both sites and its sources.

In the studied regions, soils are mostly acidophilic and organic, developed on peat bogs, alkaline precipitations have a great impact on them (Keresztesi et al., 2018). Alkaline precipitation should be treated with the same importance as acid rain, since it can lead to changes in the autochthone vegetation and to the disappearance of some species. It was observed, that during the driest year, more precipitations occurred having alkaline pH (Szép et al., 2017c). Due to lesser dilution, the concentrations of the alkaline aerosols increase (Anatolaki and Tsitouridou, 2009), which can also explain the higher $\mathrm{pH}$ values. The aim of this study is to report and to evaluate the differences between two regions in the Eastern Carpathians, assessing the chemical characteristics of precipitation chemistry at Miercurea Ciuc (Intra-Carpathian Region) and Odorheiu Secuiesc (Extra-Carpathian Region) in 2013. These results are important in order to understand the specific microclimate conditions at Miercurea Ciuc, and can contribute in the development of regional and national specific policies for the protection of the atmosphere, that can be further used in the United Nations strategy as well.

\section{Materials and Methods}

During the one-year period, at each sampling site 22 rainwater samples were collected. To determine quantitatively the anions and cations, ion chromatograph and atomic absorption techniques were used. The anions $\left(\mathrm{SO}_{4}{ }^{2-}, \mathrm{NO}_{3}^{-}, \mathrm{NO}_{2}^{-}\right)$were analyzed by Ion Chromatograph (Dionex 2000i/SP). Cations $\left(\mathrm{Na}^{+}, \mathrm{Ca}^{2+}, \mathrm{Mg}^{2+}\right.$ and $\left.\mathrm{K}^{+}\right)$were quantitatively determined by atomic absorption (AAS, Perkin Elmer, model 2380, Air/ $\mathrm{C}_{2} \mathrm{H}_{2}, 422.7 \mathrm{~nm}$ ). The $\mathrm{Cl}^{-}$ and $\mathrm{NH}_{4}{ }^{+}$were measured by U-VIS spectrometer method (Nicolet Evolution 100, 463 and $440 \mathrm{~nm}$ ) (Szép et al., 2017c). After each collection, pH was measured, using digital $\mathrm{pH}$ meters standardized with 4.0 and $9.2 \mathrm{pH}$ buffer solutions. In order to verify the completeness of the measured major constituents, the ionic balance was calculated. Data is generally considered 
acceptable if the equivalent ratio of the $\Sigma$ anions $/ \Sigma$ cations is around one, with ion imbalances that does not exceed $\pm 25 \%$ (Keene et al., 1986; Wu et al., 2016). The ratio of total anions to total cations was $0.90 \pm 0.34$ and $0.80 \pm 0.46$ for Miercurea Ciuc and Odorheiu Secuiesc, respectively. Unpolluted natural rain water has a $\mathrm{pH}$ value around 5.6, as the naturally existing $\mathrm{CO}_{2}, \mathrm{NO}_{\mathrm{x}}$ and $\mathrm{SO}_{2}$ gets dissolved in rain drops (Bayraktar and Turalioglu, 2005; Charlson and Rodhe, 1982). Any change in the $\mathrm{pH}$, below or above this level, defines rain to be acidic or alkaline, depending upon the type of pollutants transferred to rainwater (Singh et al., 2016).

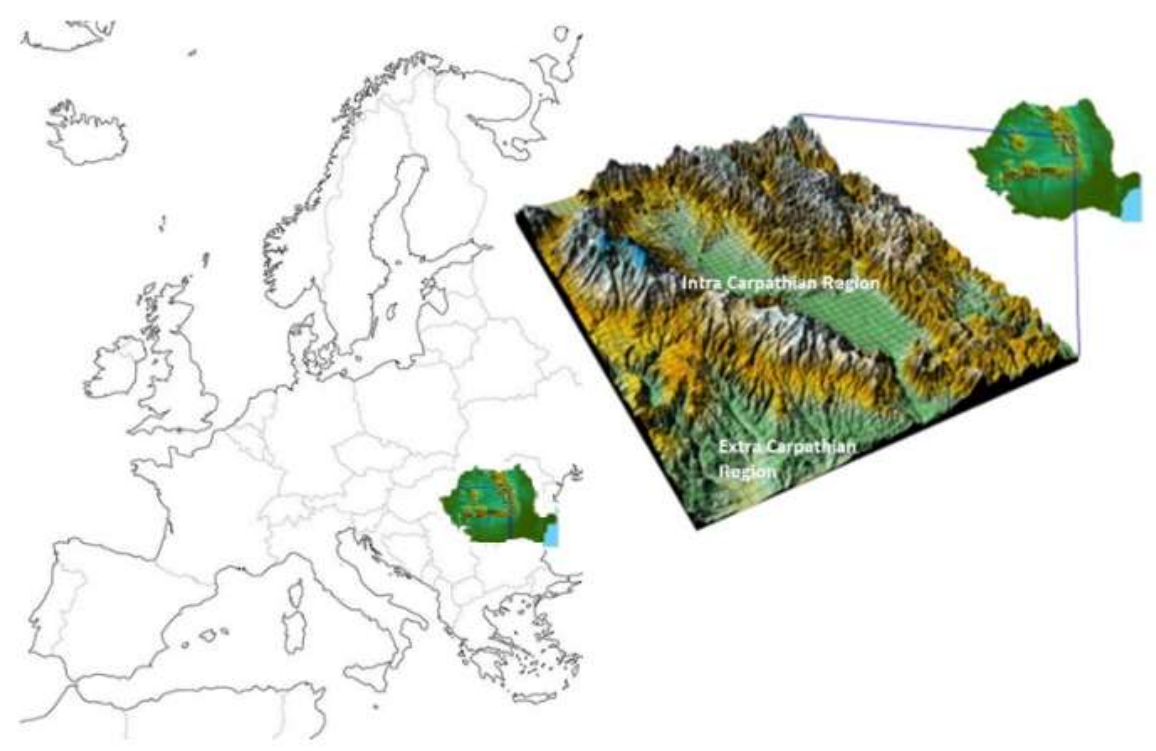

Fig. 1. The sampling sites, Miercurea Ciuc (Intra-Carpathian Region) and Odorheiu Secuiesc (Extra-Carpathian Region), Eastern Carpathians, Romania (map source: www.cartograf.fr ; map modeling: Surfer and MS Paint)

\section{Results and Discussion}

In Miercurea Ciuc and Odorheiu Secuiesc, the measured $\mathrm{pH}$ values show alkaline character for both sampling sites, being higher than 5.6. The average $\mathrm{pH}$ value measured for Miercurea Ciuc was $7.08 \pm 0.21$ and the volume weighted mean (VWM) 7.12, while for Odorheiu Secuiesc the mean value was $7.20 \pm 0.27$, and the VWM 7.17. Rainwater with $\mathrm{pH}$ value below 5.0 is due to the presence of natural $\mathrm{H}_{2} \mathrm{SO}_{4}$, weak organic acids, or anthropogenic emission of $\mathrm{H}_{2} \mathrm{SO}_{4}$ and/or $\mathrm{HNO}_{3}$ (Wang and Han, 2011). The higher alkalinity may be 
due to suspension of particles in the atmosphere, rich in carbonates and bicarbonates of calcium, magnesium, which buffers the acidity generated by mineral acid (Salve et al., 2008). The pH was alkaline in all the samples as compared to the reference level (5.6). The total sum of ions (measured chemical constituents) during 2013 for Miercurea Ciuc and Odorheiu Secuiesc were $9915.82 \pm 762.89 \mu \mathrm{eq} / 1$ and $13597.52 \pm 1313.19 \mu \mathrm{eq} / \mathrm{l}$, respectively. The anionic balance of rainwater samples showed $\mathrm{HCO}_{3}{ }^{-}>\mathrm{SO}_{4}{ }^{2-}>\mathrm{Cl}^{-}>\mathrm{NO}_{3}{ }^{-}>$ $\mathrm{NO}_{2}^{-}$for Miercurea Ciuc, and $\mathrm{SO}_{4}{ }^{2-}>\mathrm{HCO}_{3}^{-}>\mathrm{Cl}^{-}>\mathrm{NO}_{3}{ }^{-}>\mathrm{NO}_{2}^{-}$for Odorheiu Secuiesc. The downward order for sum of cations in Miercurea Ciuc was $\mathrm{NH}_{4}^{+}>\mathrm{Ca}^{2+}>\mathrm{Na}^{+}>\mathrm{K}^{+}>\mathrm{Mg}^{2+}>\mathrm{H}^{+}$, while in Odorheiu Secuiesc the cations followed $\mathrm{Ca}^{2+}>\mathrm{NH}_{4}^{+}>\mathrm{Na}^{+}>\mathrm{K}^{+}>\mathrm{Mg}^{2+}>\mathrm{H}^{+}$. In Miercurea Ciuc the rainwater chemistry is influenced by the following ionic constituents: $\mathrm{NH}_{4}{ }^{+}$ $(\sim 26 \%), \mathrm{Ca}^{2+}(\sim 16 \%)$, and $\mathrm{HCO}_{3}^{-}(\sim 14 \%)$, while in Odorheiu Secuiesc $\mathrm{Ca}^{2+}$ ( $29 \%), \mathrm{SO}_{4}{ }^{2-}(23 \%)$ and $\mathrm{NH}_{4}{ }^{+}(\sim 19 \%)$ contribute the most. For both regions, the total cations contribute more to the composition of rainwater chemistry than anions (Salve et al., 2008). The high neutralization potential was in accordance with the atmospheric abundance of $\mathrm{Ca}^{2+}, \mathrm{Mg}^{2+}$ and $\mathrm{NH}_{4}{ }^{+}$ions, which are the main neutralizing agents in precipitation, due to the higher concentrations of particulate matter under stable atmospheric conditions with small amount of precipitation. The high $\mathrm{NH}_{4}{ }^{+}$value registered in Miercurea Ciuc is due to the Ciuc basins specific climate conditions. In Odorheiu Secuiesc, the number of cations is with $\sim 19 \%$ greater, while the number of anions is with $1.8 \%$ smaller than in Miercurea Ciuc, which is due to the cloudy systems loaded with regional precipitations. According to Bisht et al. (2017), acidity originates primarily from sulfuric and nitric acid and is neutralized by $\mathrm{Ca}^{2+}, \mathrm{NH}_{4}{ }^{+}$and $\mathrm{Mg}^{2+}$. The ratio of $\left(\mathrm{SO}_{4}{ }^{2-}+\mathrm{NO}_{3}{ }^{-}\right) /\left(\mathrm{Ca}^{2+}+\mathrm{Mg}^{2+}\right), 0.94$ for Miercurea Ciuc and 0.92 for Odorheiu Secuiesc, can be considered as indicator for acidity, if the ratio is less than one.

The value of ammonia availability index (AAI) expressed as:

$$
A A I=\frac{\left[\mathrm{NH}_{4}^{+}\right]}{2\left[\mathrm{SO}_{4}^{2-}\right]+\left[\mathrm{NO}_{3}^{-}\right]} * 100(1)
$$

(Chu, 2004), indicates that $\mathrm{NH}_{4}{ }^{+}$isn't the only responsible for the total neutralization. AAI for Odorheiu Secuiesc $(57 \%)$ is $<100 \%$, showing the ammonium deficit. In Miercurea Ciuc, AAI (93\%) indicates a nearly total neutralization of the rainwaters acidity by $\mathrm{NH}_{4}{ }^{+}$, favored by the peaty soils and the static stability of the atmosphere. The ratio of $\mathrm{H}^{+} /\left(\mathrm{SO}_{4}{ }^{2-}+\mathrm{NO}_{3}{ }^{-}\right)$observed as 0.0016 and 0.0003 for Miercurea Ciuc and Odorheiu Secuiesc, respectively, is also an indicator to determine the extent of the neutralization process in 
precipitation. This ratio, with a value close to zero indicates extensive neutralization, whereas value close to one indicates a lack of neutralization in precipitation (Bisht et al., 2017). The average ratio of $\left(\mathrm{NO}_{3}{ }^{-}+\mathrm{Cl}^{-}\right) / \mathrm{SO}_{4}{ }^{2-}$ observed as 1.53 for Miercurea Ciuc indicates that nitric and hydrochloric acid influences the acidity of rainwater, whereas the ratio below one (0.59) for Odorheiu Secuiesc, indicates the influence of sulfuric acid (Salve et al., 2008). The ratio of $\mathrm{NH}_{4}^{+} / \mathrm{NO}_{3}{ }^{-}$and $\mathrm{NH}_{4}{ }^{+} / \mathrm{SO}_{4}{ }^{2-}$ was observed as 6.80 and 3.01 for Miercurea Ciuc, 8.71 and 1.20 for Odorheiu Secuiesc, respectively. The results indicate that the acidic components of rainwater are probably neutralized by $\mathrm{NH}_{4}{ }^{+}$and possible compounds may predominate in the atmosphere in the form of $\mathrm{NH}_{4} \mathrm{NO}_{3}$ and $\left(\mathrm{NH}_{4}\right)_{2} \mathrm{SO}_{4}$ (Seinfeld, 1986). The ratio of $\left(\mathrm{Ca}^{2+}+\mathrm{NH}_{4}{ }^{+}\right) /\left(\mathrm{NO}_{3}{ }^{-}\right.$ $+\mathrm{SO}_{4}{ }^{2-}$ ) is 2.95 for Miercurea Ciuc and 2.19 for Odorheiu Secuiesc, which indicates that $\mathrm{Ca}^{2+}$ and $\mathrm{NH}_{4}{ }^{+}$ions play an important role in the neutralization process of acids in precipitation. The average value of $\mathrm{NO}_{3}{ }^{-} / \mathrm{SO}_{4}{ }^{2-}$ for Miercurea Ciuc (0.80) and Odorheiu Secuiesc (0.34) indicates that about 68\% of sulfuric acid and $32 \%$ of nitric acid contributes to the acidity in rainwater. The ratio of $\left(\mathrm{SO}_{4}{ }^{2-}+\mathrm{NO}_{3}^{-}\right) /\left(\mathrm{Ca}^{2+}+\mathrm{Mg}^{2+}\right)$ was observed as 0.97 and 0.92 for Miercurea Ciuc and Odorheiu Secuiesc, respectively, which are below unity showing the alkaline nature of rainwater (Bisht et al., 2017).

Neutralization factors (NF) show the interactions between acidic and alkaline constituents in rainwater, the effect of the alkaline compounds in the neutralization process (Rao et al., 2016), and can be calculated using the following equation by Kulshrestha et al. (1995):

$$
N F_{x i}=\frac{\left[X_{i}\right]}{\left[\mathrm{SO}_{4}^{2-}\right]+\left[\mathrm{NO}_{3}^{-}\right]}
$$

where, $\left[X_{i}\right]$ is the concentration of the alkaline component $\left(\mathrm{Ca}^{2+}, \mathrm{NH}_{4}{ }^{+}, \mathrm{Na}^{+}\right.$, $\mathrm{Mg}^{2+}$ ) expressed in $\mu \mathrm{eqL} \mathrm{L}^{-1}$. The $\mathrm{NF}_{\mathrm{NH} 4}$ was higher than the $\mathrm{NF}_{\mathrm{Na}}, \mathrm{NF}_{\mathrm{Ca}}, \mathrm{NF}_{\mathrm{K}}$ and $\mathrm{NF}_{\mathrm{Mg}}$, the factors being $1.52\left(\mathrm{NH}_{4}^{+}\right), 0.38\left(\mathrm{Na}^{+}\right), 0.98\left(\mathrm{Ca}^{2+}\right), 0.25\left(\mathrm{~K}^{+}\right)$and $0.22\left(\mathrm{Mg}^{2+}\right)$ at Miercurea Ciuc. The higher neutralizing value of $\mathrm{NH}_{4}{ }^{+}$is due to the local pollutant accumulation, which is favored by the blocking effect of the Harghita Mountains, obstructing the air masses (Szép et al., 2018), while the static stability prevents the mixing of pollutants. In the case of Odorheiu Secuiesc, calcium had the highest neutralization effect, the value of $\mathrm{NF}_{\mathrm{Ca}}$ being 1.35 , in comparison with the values calculated for $\mathrm{NH}_{4}{ }^{+}(0.84), \mathrm{Na}^{+}(0.26), \mathrm{K}^{+}$ $(0.20)$ and $\mathrm{Mg}^{2+}(0.11)$. The higher values of the neutralization factor of $\mathrm{NH}_{4}^{+}$, $\mathrm{Ca}^{2+}$ and $\mathrm{Mg}^{2+}$ indicates the important role of these in neutralizing the acidity in rainwater provided by $\mathrm{H}_{2} \mathrm{SO}_{4}$ and $\mathrm{HNO}_{3}$. 
Spearman's rank correlation analysis at 0.634 significance level and 0.001 P-value, was applied to evaluate the correlation between ions in rainwater collected at both locations (Table 1) and helps to identify the sources of the chemical species and the sources of their components.

Table 1 Correlation coefficients of ionic constituents in rainwater

\begin{tabular}{|c|c|c|c|c|c|c|c|c|c|c|}
\hline \multicolumn{3}{|c|}{ Miercurea Ciuc } & & & & & & \multicolumn{3}{|c|}{ Odorheiu Secuiesc } \\
\hline & $\mathrm{Na}^{+}$ & $\mathrm{K}^{+}$ & $\mathrm{Ca}^{2+}$ & $\mathrm{Mg}^{2+}$ & $\mathrm{SO}_{4}^{2-}$ & $\mathrm{Cl}^{-}$ & $\mathrm{NO}_{2}^{-}$ & $\mathrm{NO}_{3}^{-}$ & $\mathrm{NH}_{4}{ }^{+}$ & $\mathrm{HCO}_{3}$ \\
\hline $\mathrm{Na}^{+}$ & 1 & $.97 *$ & $.90^{*}$ & $.85^{*}$ & $.45^{*}$ & $.66^{*}$ & $.83^{*}$ & $.50 *$ & $.88^{*}$ & $.81 *$ \\
\hline $\mathrm{K}^{+}$ & .10 & 1 & .90 & $.92 *$ & $.58^{*}$ & $.69 *$ & $.48 *$ & $.07 *$ & $.62 *$ & $.81 *$ \\
\hline $\mathrm{Ca}^{2+}$ & .74 & .44 & 1 & $.95 *$ & $.78 *$ & $.66^{*}$ & $.52 *$ & $.06^{*}$ & $.64 *$ & $.92 *$ \\
\hline $\mathrm{Mg}^{2+}$ & .43 & .69 & .78 & 1 & $.73 *$ & $.68^{*}$ & $.50^{*}$ & $.10^{*}$ & $.55^{*}$ & $.87 *$ \\
\hline $\mathrm{SO}_{4}{ }^{2-}$ & .35 & .55 & .41 & .41 & 1 & $.75^{*}$ & $.37 *$ & $.30 *$ & $.41 *$ & $.57 *$ \\
\hline $\mathrm{Cl}^{-}$ & .81 & .31 & .83 & .60 & .51 & 1 & $.26^{*}$ & $.10^{*}$ & $.26^{*}$ & $.43 *$ \\
\hline $\mathrm{NO}_{2}^{-}$ & .83 & .16 & .70 & .55 & .35 & .90 & 1 & $.27 *$ & .85 & $.60 *$ \\
\hline $\mathrm{NO}_{3}^{-}$ & .83 & .29 & .83 & .57 & .45 & .79 & .71 & 1 & $.38 *$ & $-.26 *$ \\
\hline $\mathrm{NH}_{4}^{+}$ & .09 & .94 & .39 & .65 & .56 & .33 & .19 & .16 & 1 & $.69 *$ \\
\hline $\mathrm{HCO}_{3}^{-}$ & .11 & .74 & .48 & .62 & .56 & .38 & .16 & .30 & .74 & 1 \\
\hline
\end{tabular}

The correlations obtained for $\mathrm{Ca}^{2+}$ and $\mathrm{Mg}^{2+}(0.95), \mathrm{K}^{+}$and $\mathrm{Mg}^{2+}(0.97)$, $\mathrm{K}^{+}$and $\mathrm{Ca}^{2+}(0.90)$, respectively, for Odorheiu Secuiesc and the correlations between $\mathrm{Ca}^{2+}$ and $\mathrm{Mg}^{2+}(0.78)$, and between $\mathrm{K}^{+}$and $\mathrm{Mg}^{2+}(0.69)$ for Miercurea Ciuc, indicate that the presence of these cations can be associated to the same sources, re-suspension of soil and crustal origin. Strong correlations between $\mathrm{Na}^{+}$and $\mathrm{Ca}^{2+}(0.74)$ and $\mathrm{Cl}^{-}(0.81)$ in the case of Miercurea Ciuc and between $\mathrm{Na}^{+}$and $\mathrm{Cl}^{-}(0.66), \mathrm{K}^{+}(0.97), \mathrm{Ca}^{2+}(0.90)$ for Odorheiu Secuiesc were considered originated from sea salt aerosol with soil contribution, but the lower correlation for Miercurea Ciuc is due to the numerous mofette emanations and mineral springs, frequently present in the Ciuc basin. The correlation matrix also indicates that a strong relationship exists between $\mathrm{Cl}^{-}, \mathrm{NO}_{2}{ }^{-}$and $\mathrm{NO}_{3}{ }^{-}$, which may probably be due to their similar source or photochemical processes, also partial correlation found between nitrate and sulfate suggests similar trends in occurrence and abundance, as both are constituents of polluted urban atmospheres (Nangbes et al. 2014). The significant correlation between, $\mathrm{NO}_{2}{ }^{-}$ and $\mathrm{NO}_{3}^{-}(0.71)$, indicate their origin from similar sources and similar behavior in precipitation. Other relatively significant correlations were observed between $\mathrm{Ca}^{2+}$ and $\mathrm{NO}_{2}{ }^{-}(0.70), \mathrm{Ca}^{2+}$ and $\mathrm{NO}_{3}{ }^{-}(0.83)$ for Miercurea Ciuc and between $\mathrm{Ca}^{2+}$ and $\mathrm{SO}_{4}^{-}(0.78), \mathrm{SO}_{4}^{-}$and $\mathrm{Cl}^{-}(0.75)$ for Odorheiu Secuiesc. 
Significant correlations were observed among the ions such as $\mathrm{HCO}_{3}{ }^{-}$and soil derived $\mathrm{Ca}^{2+}(0.92), \mathrm{CaCO}_{3}$, and $\mathrm{K}^{+}(0.81)$ at Odorheiu Secuiesc derived from fertilization and biomass burning, while correlation between $\mathrm{K}^{+}$and $\mathrm{HCO}_{3}{ }^{-}$ (0.74) can be observed at Miercurea Ciuc too. The above-mentioned ions mostly have secondary pollution sources or occur in rainwater as a result of atmospheric chemical reactions (Rao et al., 2016). Good correlations were found between $\mathrm{Ca}^{2+}$ and $\mathrm{NH}_{4}{ }^{+}(0.64), \mathrm{NH}_{4}{ }^{+}$and $\mathrm{HCO}_{3}{ }^{-}(0.69), \mathrm{Na}^{+}(0.88), \mathrm{K}^{+}$ (0.62), and between $\mathrm{NH}_{4}{ }^{+}$and $\mathrm{NO}_{2}^{-}$(0.85), respectively, for Odorheiu Secuiesc. Ammonium is available in the atmosphere as a secondary inorganic aerosol, which is produced from fertilizers used by farmers during agricultural activities or urine excretion (Kaya and Tuncel, 1997). At Miercurea Ciuc, the correlation between $\mathrm{NH}_{4}{ }^{+}$and $\mathrm{HCO}_{3}{ }^{-}(0.74)$, and $\mathrm{NH}_{4}{ }^{+}$and $\mathrm{K}^{+}(0.94)$ was also significant, showing the same source origin, like biomass burning and the peat fires events, which are frequent during droughts. The significant correlation between $\mathrm{Mg}^{2+}$ and $\mathrm{NH}_{4}^{+}(0.65)$ in Miercurea Ciuc and between $\mathrm{Ca}^{2+}$ and $\mathrm{NH}_{4}^{+}$ (0.64) could also indicate the effect of nitrogenous fertilizers, cattle wastes and soil particulates (Bisht et al., 2017).

The chemical compositions of rainwater are expected to reflect the relative contribution of the ions from these reservoirs (Safai et al., 2004). In order to quantify the contribution of sea salt (SS) and non-sea salt (NSS) to precipitation chemistry, the sodium is assumed to be of marine origin and it is used as a reference element ( $\mathrm{Wu}$ et al., 2016). The ratio values for both locations with respect to sea salt, non-sea salt and enrichment factor are presented in Table 2 .

Table 2. Ratio values of ions, SSF (sea salt fraction), NSSF (non-sea salt fraction) and EF (enrichment factor)

\begin{tabular}{|c|c|c|c|c|c|}
\hline & $\frac{C l^{-}}{N a^{+}}$ & $\frac{K^{+}}{N a^{+}}$ & $\frac{\mathrm{Ca}^{2+}}{\mathrm{Na}^{+}}$ & $\frac{\mathrm{Mg}^{2+}}{\mathrm{Na}^{+}}$ & $\frac{\mathrm{SO}_{4}^{2-}}{\mathrm{Na}^{+}}$ \\
\hline Seawater & 1.16 & 0.02 & 0.04 & 0.22 & 0.12 \\
\hline \multicolumn{6}{|c|}{ Miercurea Ciuc/Odorheiu Secuiesc } \\
\hline $\begin{array}{l}\text { Mean } \\
\text { value }\end{array}$ & $1.45 / 1.33^{*}$ & $0.62 / 1.05^{*}$ & $2.37 / 7.23 *$ & $0.53 / 0.61^{*}$ & $2.05 / 5.54^{*}$ \\
\hline$\% \mathrm{SSF}$ & $79.84 / 87.27^{*}$ & $3.23 / 1.91 *$ & $1.69 / 0.55^{*}$ & $41.78 / 36.02 *$ & $5.85 / 2.17 *$ \\
\hline$\% \mathrm{NSSF}$ & $20.16 / 12.73 *$ & $96.77 / 98.09 *$ & $98.31 / 99.45^{*}$ & $58.22 / 63.98^{*}$ & $94.15 / 97.83 *$ \\
\hline$\% \mathrm{EF}$ & $1.25 / 1.15^{*}$ & $31.00 / 52.37 *$ & $59.17 / 180.65 *$ & $2.39 / 2.78^{*}$ & $17.10 / 46.15^{*}$ \\
\hline
\end{tabular}

* - Odorheiu Secuiesc

The enrichment factor for all elements in both locations is higher than one, which indicates the significant influence of local sources. The observed 
rainwater ratio of $\mathrm{Cl}^{-} / \mathrm{Na}^{+}$for Miercurea Ciuc (1.45) and Odorheiu Secuiesc (1.33) is higher than that of seawater ratio (1.16), indicating that the $\mathrm{Cl}^{-}$in rainwater, beside maritime sources, is also influenced by the local contribution of numerous mofette emanations and mineral springs. The sea salt fraction (SSF) of $\mathrm{Cl}^{-}$was observed to be the highest in both areas, 79.84 for Miercurea Ciuc and 87.27 for Odorheiu Secuiesc. The higher SSF in case of Odorheiu Secuiesc can be explained by the presence of sea salt aerosols, carried with precipitations coming from the sea, as well as the presence of a nearby salt mine (Praid). The area of Miercurea Ciuc is surrounded by the Harghita Mountains, which act as a barrier, blocking the regional fronts loaded with sea salts, while due to the specific climate, local precipitations are more frequent, explaining a lower contribution of SSF. The values of non-sea salt (NSS) contributions of ionic constituents ranged between 20.16 and 98.31 for Miercurea Ciuc and between 12.73 and 99.45 for Odorheiu Secuiesc. The high non-sea salt fraction (NSSF) values for $\mathrm{K}^{+}, \mathrm{Ca}^{2+}, \mathrm{Mg}^{2+}$ in case of both locations, show that these ions originate from crustal sources, also proven by the regression analysis between soil-derived $\mathrm{Ca}^{2+}$ and $\mathrm{Mg}^{2+}(\mathrm{R}=0.61$ for Miercurea Ciuc; $\mathrm{R}=0.94$ for Odorheiu Secuiesc), while the main cause for high NSSF $\mathrm{SO}_{4}{ }^{2-}$ values are emissions, due to anthropogenic activities. The high NSSF value of potassium in the atmosphere can originate from both coarse mineral particles and fine biomass burning particles (Falkovich et al., 2005).

Table 3 Varimax rotated factor loadings, total variance and ionic sources

\begin{tabular}{|c|c|c|c|c|c|c|}
\hline & F1 & F1* & $\mathrm{F} 2$ & $\mathrm{~F} 2 *$ & $\mathrm{~F} 3$ & $\mathrm{~F} 3 *$ \\
\hline $\mathrm{Na}^{+}$ & 0.039 & 0.563 & 0.929 & 0.731 & 0.042 & 0.223 \\
\hline $\mathrm{K}^{+}$ & 0.794 & 0.613 & 0.029 & 0.239 & 0.161 & 0.338 \\
\hline $\mathrm{Ca}^{2+}$ & 0.969 & 0.845 & 0.521 & 0.394 & 0.143 & 0.142 \\
\hline $\mathrm{Mg}^{2+}$ & 0.890 & 0.858 & 0.385 & 0.347 & 0.047 & 0.250 \\
\hline $\mathrm{SO}_{4}^{2-}$ & 0.318 & 0.119 & 0.198 & 0.435 & 0.898 & 0.728 \\
\hline $\mathrm{Cl}^{-}$ & 0.125 & 0.306 & 0.886 & 0.897 & 0.237 & 0.184 \\
\hline $\mathrm{NO}_{3}{ }^{-}$ & 0.265 & 0.123 & 0.011 & 0.044 & 0.912 & 0.632 \\
\hline $\mathrm{NH}_{4}^{+}$ & 0.933 & 0.865 & 0.081 & 0.391 & 0.246 & 0.121 \\
\hline$\%$ Total variance & 37.83 & 39.65 & 27.19 & 36.22 & 25.37 & 18.22 \\
\hline Source & \multicolumn{2}{|c|}{$\begin{array}{l}\text { Crustal and } \\
\text { fertilization }\end{array}$} & Marine & & \multicolumn{2}{|c|}{ Anthropogenic } \\
\hline
\end{tabular}

In order to a further analyze of the relationship between the ionic constituents and to identify the possible sources, Principal Component Analysis (PCA) was applied to the dataset for both areas, using IBM SPSS version 23 Statistics software. 
As shown in Table 3, three factors have been extracted in both cases, explaining the $90.39 \%$ of the total variance at Miercurea Ciuc, and the $94.09 \%$ of the total variance at Odorheiu Secuiesc. Factor one has high loadings of $\mathrm{K}^{+}$, $\mathrm{Ca}^{2+}, \mathrm{Mg}^{2+}$ and $\mathrm{NH}_{4}{ }^{+}$for Miercurea Ciuc, and high loadings of $\mathrm{Na}^{+}, \mathrm{K}^{+}, \mathrm{Ca}^{2+}$, $\mathrm{Mg}^{2+}$ and $\mathrm{NH}_{4}{ }^{+}$for Odorheiu Secuiesc. These loadings of the above-mentioned ions are likely to be associated with crustal sources and use of fertilizers in agricultural activities. The high loading of potassium can also be associated with biomass burning. The second factor in both cases can be associated with the marine influence, due to the high value of chlorine and sodium. Factor three, in the Miercurea Ciuc, as well as in the Odorheiu Secuiesc, presented has high loadings for $\mathrm{NO}_{3}{ }^{-}$and $\mathrm{SO}_{4}{ }^{2-}$, which is associated with the secondary aerosol source, such as the chemical transformation of $\mathrm{SO}_{2}, \mathrm{NO}_{\mathrm{x}}$ on the surface of the aerosols (Falkovich et al., 2005).

As the air-mass back trajectory analysis suggested, the air masses which mainly came from north and north-northwest areas (oceanic fronts), have regional characteristics. They transport higher amounts of precipitation and higher loadings of chlorine. These values (averages) were: $108.54 \mu \mathrm{eqL} \mathrm{L}^{-1}$ for Miercurea Ciuc and $113.89 \mu \mathrm{eqL} \mathrm{L}^{-1}$ for Odorheiu Secuiesc. While, the concentrations for $\mathrm{Cl}^{-}$from local precipitations, lasting a shorter period of time, were: $21.76 \mu \mathrm{eqL}^{-1}$ for Miercurea Ciuc and $36.03 \mu \mathrm{eqL} \mathrm{L}^{-1}$ for Odorheiu Secuiesc.

\section{Conclusions}

The present study was conducted to evaluate the differences between the precipitation chemistry of Miercurea Ciuc and Odorheiu Secuiesc, in the Eastern Carpathians, Romania during 2013, the driest year of the last decade. Miercurea Ciuc is surrounded by the Harghita Mountains, which act as a barrier blocking the regional fronts loaded with sea salts, while due to the specific climate, local precipitations are more frequent, explaining a lower contribution of marine influence. PCA helped identify the possible sources, sustaining the barrier effect of the Harghita mountains, since marine sources had higher factor loadings at Odorheiu Secuiesc. The rainwater samples showed alkaline nature, with average $\mathrm{pH}$ values much higher in both regions than the reference value of 5.6. The average $\mathrm{pH}$ value measured at Miercurea Ciuc was 7.08, while at Odorheiu Secuiesc the mean value was 7.20. In Miercurea Ciuc the rainwater chemistry is influenced mostly by $\mathrm{NH}_{4}{ }^{+}$, while in Odorheiu Secuiesc $\mathrm{Ca}^{2+}$ contributes the most. The high $\mathrm{NH}_{4}{ }^{+}$value registered in Miercurea Ciuc is due to the Ciuc basins local specific climate conditions. At Odorheiu Secuiesc, the number of cations is with $\sim 19 \%$ greater, while the 
number of anions is with $1.8 \%$ smaller than in Miercurea Ciuc, which is due to the cloudy systems loaded with regional precipitations. The calculation of the $\mathrm{NF}$ supported the above-mentioned fact, the main neutralizing agent in Miercurea Ciuc being the ammonium ion with a NF value of 1.52 , while in Odorheiu Secuiesc calcium was the most responsible in the neutralization process, with a NF value of 1.35. The correlations obtained for $\mathrm{Ca}^{2+}$ and $\mathrm{Mg}^{2+}$ (0.95), $\mathrm{K}^{+}$and $\mathrm{Mg}^{2+}(0.97), \mathrm{K}^{+}$and $\mathrm{Ca}^{2+}(0.90)$, respectively, for Odorheiu Secuiesc and the correlations between $\mathrm{Ca}^{2+}$ and $\mathrm{Mg}^{2+}(0.78)$, and between $\mathrm{K}^{+}$ and $\mathrm{Mg}^{2+}(0.69)$ for Miercurea Ciuc, indicate that the presence of these cations can be associated to the same sources, re-suspension of soil and crustal origin. The sea salt fraction (SSF) of $\mathrm{Cl}^{-}$was observed to be the highest in both areas, 79.84 for Miercurea Ciuc and 87.27 for Odorheiu Secuiesc. The higher SSF in case of Odorheiu Secuiesc can be explained by the presence of sea salt aerosols, carried with precipitations coming from the sea.

Acknowledgements: The authors wish to thank the Romanian National Meteorological Administration and the Environmental Protection Agency Harghita for permission to use rainwater chemical data.

This research did not receive any specific grant from funding agencies in the public, commercial, or not-for-profit sectors.

\section{References}

Anatolaki, C., Tsitouridou, R., 2009. Relationship between acidity and ionic composition of wet precipitation. A two years study at an urban site, Thessaloniki, Greece. Atmos. Res. 92, 100-113. doi:10.1016/j.atmosres.2008.09.008

Anderson, K.A., Downing, J.A., 2006. Dry and wet atmospheric deposition of nitrogen, phosphorus and silicon in an agricultural region. Water. Air. Soil Pollut. 176, 351-374. doi:10.1007/s11270-006-9172-4

Bayraktar, H., Turalioglu, F.S., 2005. Composition of wet and bulk deposition in Erzurum, Turkey. $\quad$ Chemosphere 59, 1537-1546. doi:10.1016/j.chemosphere.2005.02.013

Behera, S.N., Sharma, M., Aneja, V.P., Balasubramanian, R., 2013. Ammonia in the atmosphere: A review on emission sources, atmospheric chemistry and deposition on terrestrial bodies. Environ. Sci. Pollut. Res. 20, 8092-8131. doi:10.1007/s11356-013-2051-9

Bisht, D.S., Srivastava, A.K., Joshi, H., Ram, K., Singh, N., Naja, M., Srivastava, M.K., Tiwari, S., 2017. Chemical characterization of rainwater at a high-altitude site "Nainital" in the central Himalayas, India. Environ. Sci. Pollut. Res. 24, 3959-3969. doi:10.1007/s11356-016-8093-z

Charlson, R.J., Rodhe, H., 1982. Factors controlling the acidity of natural rainwater. 
30 Ágnes Keresztesi, Réka Boga, Zsolt Bodor, Katalin Bodor, Szende Tonk, György Deák, I.-A. Nita

Nature 295, 683-685. doi:10.1038/295683a0

Chate, D.M., Rao, P.S.P., Naik, M.S., Momin, G.A., Safai, P.D., Ali, K., 2003. Scavenging of aerosols and their chemical species by rain. Atmos. Environ. 37, 2477-2484. doi:10.1016/S1352-2310(03)00162-6

Chu, S.H., 2004. PM2.5 episodes as observed in the speciation trends network. Atmos. Environ. 38, 5237-5246. doi:10.1016/j.atmosenv.2004.01.055

Ciężka, M., Modelska, M., Górka, M., Trojanowska-Olichwer, A., Widory, D., 2015. Chemical and isotopic interpretation of major ion compositions from precipitation: A one-year temporal monitoring study in Wrocław, SW Poland. J. Atmos. Chem. 73, 61-80. doi:10.1007/s10874-015-9316-2

Cugerone, K., De Michele, C., Ghezzi, A., Gianelle, V., 2017. Aerosol removal due to precipitation and wind forcings in Milan urban area. J. Hydrol. doi:10.1016/j.jhydrol.2017.06.033

Falkovich, A.H., Graber, E.R., Schkolnik, G., Rudich, Y., Maenhaut, W., Artaxo, P., 2005. Low molecular weight organic acids in aerosol particles from Rondônia, Brazil, during the biomass-burning, transition and wet periods. Atmos. Chem. Phys. 5, 781-797. doi:10.5194/acp-5-781-2005

Ge, B., Wang, Z., Gbaguidi, A.E., Zhang, Q., 2016. Source identification of acid rain arising over Northeast China: Observed evidence and model simulation. Aerosol Air Qual. Res. 16, 1366-1377. doi:10.4209/aaqr.2015.05.0294

J. G. Nangbes*, 1, and J. B. Nvau, 2014. Concentration and Distribution of Inorganic Ions in Rainwater of Jos and Bukuru Metropolis, Plateau State, Nigeria. IOSR J. Appl. Chem. 7, 15-25.

Kaya, G., Tuncel, G., 1997. Trace element and major ion composition of wet and dry depositon in Ankara, Turkey. Atmos. Environ. 31, 3985-3998. doi:10.1016/S1352-2310(97)00221-5

Keene, W.C., Pszenny, A.P., Galloway, J.N., Hawley, M.E., 1986. Sea-salt corrections and interpretation of constituent ratios in marine precipitation. J. Geophys. Res. 91, 6647. doi:10.1029/JD091iD06p06647

Keresztesi, Á., Petres, S., Ghita, G., Dumitru, F.D., Moncea, M.A., Ozunu, A., Szép, R., 2018. Ammonium neutralization effect on rainwater chemistry in the basins of the Eastern Carpathians-Romania. Rev. Chim. 69, 57-63.

Korodi, A., Petres, S., Keresztesi, Á., Szép, R., 2017. Sustainable development. Theory or practice?, in: International Multidisciplinary Scientific GeoConference Surveying Geology and Mining Ecology Management, SGEM. doi:10.5593/sgem 2017/54/S22.049

Kulshrestha, U.C., Sarkar, A.K., Srivastava, S.S., Parashar, D.C., 1995. Wet-only and bulk deposition studies at New Delhi (India). Water. Air. Soil Pollut. 85, 2137-2142. doi:10.1007/BF01186150

Pan, Y.-P., Zhu, X.-Y., Tian, S.-L., Wang, L.-L., Zhang, G.-Z., Zhou, Y.-B., Xu, P., Hu, B., Wang, Y.-S., 2017. Wet deposition and scavenging ratio of air pollutants during an extreme rainstorm in the North China Plain. Atmos. Ocean. Sci. Lett. 10, 348-353. doi:10.1080/16742834.2017.1343084

Pascaud, A., Sauvage, S., Coddeville, P., Nicolas, M., Croisé, L., Mezdour, A., 
Probst, A., 2016. Contrasted spatial and long-term trends in precipitation chemistry and deposition fluxes at rural stations in France. Atmos. Environ. 146, 28-43. doi:10.1016/j.atmosenv.2016.05.019

Petres, S., Korodi, A., Keresztes, R., Szép, R., 2017. Tendencies and particularities in thermic inversion episodes in the Ciuc basin - Eastern Carpathians, Romania. Sect. Appl. Environental Geophys. 445-452.

Rao, P.S.P., Tiwari, S., Matwale, J.L., Pervez, S., Tunved, P., Safai, P.D., Srivastava, A.K., Bisht, D.S., Singh, S., Hopke, P.K., 2016. Sources of chemical species in rainwater during monsoon and non-monsoonal periods over two mega cities in India and dominant source region of secondary aerosols. Atmos. Environ. 146, 90-99. doi:10.1016/j.atmosenv.2016.06.069

Safai, P.D., Rao, P.S.P., Momin, G. a., Ali, K., Chate, D.M., Praveen, P.S., 2004. Chemical composition of precipitation during 1984-2002 at Pune, India. Atmos. Environ. 38, 1705-1714. doi:10.1016/j.atmosenv.2003.12.016

Salve, P.R., Maurya, A., Wate, S.R., Devotta, S., 2008. Chemical composition of major ions in rainwater. Bull. Environ. Contam. Toxicol. 80, 242-246. doi:10.1007/s00128-007-9353-x

Seinfeld, J.H., 1986. Atmospheric Chemistry and Physics of Air Pollution.

Singh, S., Elumalai, S.P., Pal, A.K., 2016. Rain pH estimation based on the particulate matter pollutants and wet deposition study. Sci. Total Environ. 563564, 293-301. doi:10.1016/j.scitotenv.2016.04.066

Szép, R., Bodor, Z., Miklóssy, I., Niță, I.A., Oprea, O.A., Keresztesi, Á., 2019. Influence of peat fires on the rainwater chemistry in intra-mountain basins with specific atmospheric circulations (Eastern Carpathians, Romania). Sci. Total Environ. 647, 275-289. doi:10.1016/j.scitotenv.2018.07.462

Szép, R., Keresztes, R., Constantin, L., 2016a. Multi-model assessment of tropospheric ozone pollution indices of risk to human health and crops, and ozone deposition in Ciuc Depression - Romania. Rev. Chim. 67, 1-6.

Szép, R., Keresztes, R., Deák, G., Tobă, F., Ghimpusian, M., 2016b. The dry deposition of PM10 and PM2.5 to the vegetation and its health effect in the Ciuc basin. Rev. Chim. 67, 639-644.

Szép, R., Keresztes, R., Korodi, A., Tonk, S., 2017a. Study of air pollution and atmospheric stability in Ciuc basin-Romania. Rev. Chim. 68, 1763-1767.

Szép, R., Keresztes, R., Korodi, A., Tonk, S., Niculae, A.G., Birloiu, A.M., 2016c. Dew point - Indirect particulate matter pollution indicator in the Ciuc Basin Harghita, Romania. Rev. Chim. 67, 1914-1921.

Szép, R., Keresztes, R., Tonk, S., Korodi, A., Craciun, M.E., 2017b. The Examination of the Effects of Relative Humidity on the Changes of Tropospheric Ozone Concentrations in the Ciuc Basin, Romania. Rev. Chim. 2-5.

Szép, R., Mateescu, E., Nechifor, A.C., Keresztesi, Á., 2017c. Chemical characteristics and source analysis on ionic composition of rainwater collected in the Carpathians "Cold Pole," Ciuc basin, Eastern Carpathians, Romania. Environ. Sci. Pollut. Res. 24, 1-15. doi:10.1007/s11356-017-0318-2

Szép, R., Mateescu, E., Niță, A., Bîrsan, M., Zsolt, B., Keresztesi, Á., 2018. Effects 
of the Eastern Carpathians on atmospheric circulations and precipitation chemistry from 2006 to 2016 at four monitoring stations (Eastern Carpathians, Romania). Atmos. Res. 214, 311-328. doi:10.1016/J.ATMOSRES.2018.08.009

Szép, R., Mátyás, L., 2014. The Role of Regional Atmospheric Stability in High-Pm 10 Concentration Episodes in Miercurea Ciuc ( Harghita ). Carpathian J. Earth Environ. Sci. 9, 241-250.

Szép, R., Mátyás, L., Keresztes, R., Ghimpusan, M., 2016d. Tropospheric Ozone Concentrations - Seasonal and Daily Analysis and its Association with NO and NO2 as a Function of NOx in Ciuc Depression - Romania. Rev. Chim. 67, 205213.

Wang, H., Han, G., 2011. Chemical composition of rainwater and anthropogenic influences in Chengdu, Southwest China. Atmos. Res. 99, 190-196. doi:10.1016/j.atmosres.2010.10.004

Wang, X., Zhang, L., Moran, M.D., 2010. Uncertainty assessment of current sizeresolved parameterizations for below-cloud particle scavenging by rain. Atmos. Chem. Phys. 10, 5685-5705. doi:10.5194/acp-10-5685-2010

Wu, Y., Xu, Z., Liu, W., Zhao, T., Zhang, X., Jiang, H., Yu, C., Zhou, L., Zhou, X., 2016. Chemical compositions of precipitation at three non-urban sites of Hebei Province, North China: Influence of terrestrial sources on ionic composition. Atmos. Res. 181, 115-123. doi:10.1016/j.atmosres.2016.06.009

Xu, D., Ge, B., Wang, Z., Sun, Y., Chen, Y., Ji, D., Yang, T., Ma, Z., Cheng, N., Hao, J., Yao, X., 2017. Below-cloud wet scavenging of soluble inorganic ions by rain in Beijing during the summer of 2014. Environ. Pollut. 230, 963-973. doi:10.1016/j.envpol.2017.07.033

Zhang, L., Wang, X., Moran, M.D., Feng, J., 2013. Review and uncertainty assessment of size-resolved scavenging coefficient formulations for below-cloud snow scavenging of atmospheric aerosols. Atmos. Chem. Phys. 13, 10005-10025. doi:10.5194/acp-13-10005-2013 